\begin{tabular}{|c|c|}
\hline$\beth$ & $\begin{array}{c}\text { International Journal of Current Research } \\
\text { and Academic Review }\end{array}$ \\
\hline $\begin{array}{l}\text { YCELLENT } \\
\text { BLLISHERS }\end{array}$ & $\begin{array}{r}\text { ISSN: } 2347-3215 \text { (Online);,; Volume 5;,; } \\
\text { Journal homepage: http://www }\end{array}$ \\
\hline
\end{tabular}

doi: http://dx.doi.org/10.20546/ijcrar.2017.501.009

\title{
An Analysis of Electronic Governance: Deliverance of Public Electronic Services at the front desk level in India
}

\author{
Ramnik Kaur* \\ Department of Public Administration, Punjabi University, Patiala, India \\ *Corresponding author
}

\begin{abstract}
In India Citizen Challenges Administrative Challenges, Economical Challenges and Technical Challenges. This paper will be evaluating the Citizens, Administrative and Technical challenges which are faced by the citizens as well as by the front desk operator to handle the day to day deliverance of public e-services. The cultural norms and patterns of individual behavior affect the manner in which technology is used by citizens. There is need to develop effective implementation of e-government in India in order to serve the citizens. In order to match the digital divide gap in the country there is a need to develop an environment for e-government by overcoming the challenges of e-government. Implementation of e-government conceptual framework which can be further validated in the real life situation is developed for the effective implementation of e-government in India.
\end{abstract}

\begin{abstract}
Article Info
Accepted: 10 January 2017

Available Online: 20 January 2017
\end{abstract}

\section{Keywords}

Electronic Governance, Public

Electronic Services.

\section{Introduction}

The development of Information Technology and the increased access to internet in a transaction mode of the government websites soon developed into a highly potential channel for supporting a front end and back end applications (Bharat Maheshwari et al., 2007). Beyond fast delivery of services the internet technology brought in more transparency and accountability in the governance process. Therefore in developing countries like India, where most of the population lives below the poverty line, where the literacy level is also very low makes much difficult for the government to provide its services to such citizens through the internet. Withdrawn from various studies of different countries and projects there are many challenges which need to be consigned for the successful implementation of e-governance projects in India.

Developing countries like India where poverty and illiteracy place a major obstacle in any form of development under such condition it becomes very difficult to provide government services to the people. There are a large number of obstacles in implementation of e-Governance in India.

Most challenges that are expected to be faced during the implementation of an electronic Government program are basically-Infrastructure Development, Law, Digital Divide, E-Literacy, Accessibility, Trust, Privacy, Security, Transparency, Interoperability, Record 
Management, Permanent availability, Education, Marketing, Public/Private competition/collaboration, Workforce, Cost structure, and Benchmarking (Almarabeh et al., 2010). These can be categorized under the following titles: Citizen Challenges Administrative Challenges, Economical Challenges and Technical Challenges. This paper will be evaluating the Citizens, Administrative and Technical challenges which are faced by the citizens as well as by the front desk operator to handle the day to day deliverance of public e-services. These challenges are explained below:

\section{Citizens Challenges}

There are well defined factors which mandate the adoption of e-governance, although no classification of these adoption factors has been made. Adoption of egovernance by the citizen intense participation in government activity electronically in order to receive information and request services from the government (Warkentin et al., 2002). Citizen's technical awareness that is how to adapt to frequent technical changes in the services is a very important challenge of adoption ${ }^{4}$. The major challenges are as:

1. The annual income of the citizens is very low so they cannot afford the Internet services

2. They cannot pay the charges of Internet connectivity, hardware cost and installation cost.

3. There is a lack of computer literacy.

4. These charges are very high and not affordable.

5. There is lack of communication among the departments and other concerned departments.

6. Insufficient Citizen Service centers in the city of various states.

7. Inadequate infrastructure creates problem in implementing the e-governance projects. It affects transactions \& processing time.

8. The official working hours cause inconvenience to the working citizens.

9. Citizens facing a lot of difficulties at the time of using the services. There is no proper help desk to guide the process of e-governance.

10. No strategy or policy to increase citizen's confidence and trust on government services.

11. No clear and accurate information about each service \& transactions provided by government. Citizens cannot use the e-Governance channel to follow-up and track the progress of their transactions conveniently.

12. The information available on the websites is hardly updated.

13. The citizens are reluctant to adopt the online lifestyle.

\section{Suggestions}

e-Governance claims for increased efficiency and effectiveness of the government but these goals can be achieved only if the service are made available to the citizens. The government has to provide internet access through public terminals as a part of their universal access efforts. Much of the Indian people are not literate and those who are literate, they do not have much knowledge about Information Technology (IT). Users of e-Governance applications are almost non-expert users who need guidance to find the right manner to perform the transactional work.

1. Literacy level of India is very low which is considered as a huge obstacle in implementation of eGovernance projects.

2. Illiterate people are not able to access the eGovernance applications; hence the projects do not get much success.

3. Most of the people living in India are not aware about the usage of Information Technology. IT illiteracy is a major obstacle in implementing e-Governance projects in India.

4. All Indian people must be made aware about the usage of Information Technology.

5. All the citizens are to be well aware about the facilities offered by the e-government and act responsible to them so that citizens should accept these facilities. It should be society friendly.

6. The government must pay much attention to make the people aware about e-Governance activities and make it available at their best convenient locations.

7. The government websites must be user friendly so that more and more people can use them easily and to be more effective. For example; Chandigarh Sampark centre has come up with a help desk activity in order to facilitate the citizens.

8. The government websites need to be designed in an easier format so that it is more usable to users even who are not expert users of IT.

9. All the service should be accessible for anywhere and anytime (Carolyne Stanforth, 2010).

The government needs to maintain the trust and balance between ensuring a system preventing fraudulent transactions and the burden where extensive checks can take place in order to avoid corruption. People living below the poverty line cannot afford a computer and internet connection for themselves in order to avail the benefits of the e-Government services and other on-line services. In order to bridge this digital divide Indian 
government has to focus on building infrastructure to work towards effective implementation of the eGovernance projects.

\section{Administrative Challenges}

The availability and advancement of Information and Communication Technology equipments in public sector depends upon the Information and Technology act and the interest and efforts of government investment and public private partnership. The government must motivate, train and encourage users to utilize information and communication technology and equipments but there are some challenges which they face while performing their job such as:

1. The Government officers and employee have phobia of computers.

2. The employees do not wish to learn new technology.

3. The employees have fear that they will lose their job if they adopt e-Governance projects.

4. The Administrative Officers, Heads \& Section Officers of the organizations are not technically sound so they find to manage networking difficult.

5. There is lack of awareness about importance of computerization in administrative sector.

6. Most of the e-Governance projects developed with an English language interface, majority of the citizens (88\%) do not know English so localization is missing.

7. The employees are facing the language problem.

8. There is lack of training centre for the employees.

9. No adequate Citizen Service Centre in the city as per requirement of the population must be located.

10. No adequate grants are available for the e-governance project.

11. Lack of proper utilization of grants.

12. No proper proposals about the demand of funds were submitted to government.

13. There are no proper criteria for selecting experts in eGovernance projects.

14. There is lack of skilled people to handle the ICT in India.

15. No sufficient funds are available for implementation of electronic projects.

16. Due to the lack of technical knowledge, administrators do not entertain external expertise.

17. Due to the lack of proper government policies, there is lack of use of collective expertise.

18. No effective and adequate infrastructure available in government departments to implement e-Governance project.
19. Most of the departments have unreliable internet connectivity.

20. There is no proper participation of government \& citizens to improve the services.

21. Due to lack of adequate Management Information Systems, e-governance project dose not function properly.

22. There is problem of connectivity between districts place and villages.

23. There is lack of special administrative department for handling e- Governance

24. The government policies about implementation of egovernance are not strict so the employees always have the second choice. This causes ineffective implementation (Das et al., 2013).

The employees must train with the IT techniques in order to work effectively towards the deliverance of public services. The employees must know to deal with the citizens and manage the work with hardware and software techniques of information and communication. Special counseling sessions must be undertaken by the employees for the adopting the online process of services. The government must indulge employees in compulsory training program.

\section{Suggestions}

In order to reach the success of implementation of egovernance projects e-governance has advanced the functioning and working processes of various departments in order to bring efficiency of the personnel using IT techniques. Hence, the increasing efficiency and the potentiality by learning of IT techniques has resulted increase in social status, technical development and saving of time by updating the information timely and easily. The use of Information and Technology by the officials has concluded in following ways:

1. IT has resulted in speeding the efficiency, performance and grievances among the employees working process especially the one's working in banking, police, and education sector.

2. Travel and physical contact between the clients and employees of marketing and education sector has been reduced by the use of IT which also saves time of both the client and the employees.

3. The various problems while functioning by the users now with the use of IT can be easily solved through the internet and emails.

4. The government departments carry a lot of paperwork and officially took much time in 
recording and maintaining the records. Maintenance of files and keeping of records has reduced and has also resulted in saving the physical energy of the employees.

5. Through the use of IT and updated timely information quick and rational decision making helps in formulation and implementation of policy.

6. The access of information must be permitted in the local languages for users comfort. There should be language software or some other technology to translate the information from English to local languages.

7. In order to increase the productivity of the department the revenue collection, fee deposits and bill payments have turned out to be easy and speedy.

8. Automated financial transactional activities and security system helps in controlling corruption, reduced the interference of touts, saved time of the employees of the public sector.

9. Through the practice of IT easy availability of electronic data and various records to the users have resulted in checking red tapism.

10. IT has brought in a connection among various people, departments and governments which are at distant.

11. E-governance has bought in of exchanging ideas and knowledge within the departments and among other various departments connected or not connected.

12. Training of employees under the IT helps employee's skill development which results in better performance and handling errors quickly.

13. The government now days are focusing on the training and learning through -Governance Executive Training Programme (eGEP) in order to build confidence and morale among the employees in order to learn new technology to serve the citizens in a better way.

In India, therefore there are still employees who hesitate to adopt the new technology that easily. There is still fear and hesitation among the employees to use the IT techniques. They fear with the sense of crashing the data or they may hesitate to learn the new technique faster. They do not feel the use of IT that important and helpful for carrying out their work. Hence, the implementation of IT in various departments of government has resulted corporation, quick decision making, relationship of various departments and governments, online financial transactions, reduced corruption, built new confidence and brought in skill development, reduced the work of touts, saves time and physical energy of the employees and departments.
In order to promote E-Governance in the government departments the Department of Electronics and Information Technology (DeitY) came up with an egovernance training module called the e-Governance Executive Training Program (eGEP) in 2013 which was the first such national-level program for officers at the level of under secretary, section officer, deputy director, assistant director, tehsil and block level officer or equivalent. The nomination was done by their department heads and they will need five years' experience to qualify. The objective of this program was to train selected officers from within line ministries/departments, who are managing or have been identified to support/manage MMPs under the NeGP or other e-Governance projects. The program brochure uploaded on the DeitY website identified various areas that were covered as a part of the course: technology trends in hardware, software, communications and networks, cyber security management, national and international e-governance practices and more. DeitY has organized 115 such programs in the last two years for different sets of officers with different requirements (The Times of India, 2013).

Government of India through e-governance is connecting people and government in order to indulge participation of people in decision making process of government. Although the use of IT has brought improvement in performances and has skilled the employees, still there is need to encourage employees in the public sectors and also by the government and politicians at the local level for the benefits of people. There must be availability of equipments for the use of ICT to ensure at all the levels of administration and to train the employees in using hardware and software is to be introduced.

\section{Technical Challenges}

All over India the telecommunications infrastructure is still inaccessible. The government in order to support egovernment and ICT has tried to invest in infrastructure and still a lot of infrastructure problems such as obsolete equipment, infrastructure etc. are faced in few better developed metros and big cities. The implementation of e-projects at all the levels of governance face mostly the challenges of network, server down, relationship with other ministries, lack of proper knowledge among employees, technical faults due to constant use of equipment and much like mentioned below:

1. Most of the rural and urban areas lack broad band connections that require for network connectivity. 
2. The power shutdown problem creates problem in service providing.

3. There are no sufficient skilled manpower for maintaining and repairing computer systems and network.

4. The frequency of up gradation of web portal is very less. Technology needs to be up to date.

5. The application forms available on web are found in the form of old versions for long period. Local language must be an option.

6. There are many inter- links for searching information on web which involves a lot of efforts and interactions.

7. The quality of the Internet connection is very poor at times.

8. Misuse of data by officials.

9. The documents must be authorized by the Government (Dawes, 2008).

\section{Suggestions}

There is a need for each department to train their personnel about the information and communication Technology (ICT) techniques. All the department of governments at the state and centre must be interconnected through the internet. The ICT equipment must be provided to the employees with encouraging them to use the technology well.

1. Government should provide dial-up internet connectivity if there is problem for broadband connection in rural and urban areas. The system of eGovernance must use the wireless networks like existing cellular networks to reach the applications into rural areas irrespective of the geographical issues. Government should provide the high speed internet connectivity.

2. The employees of the government departments should be trained by add-on or value added training. It is better and safe to use technologies and products which are tried and tested for longer periods of times than using the latest ones.

3. Government should update web portals at least every seven days and changes in the web portal should upload within one working day. Government should design standards of systems, applications and processes across the District and State.

4. The applications provided by e-Government, their scope must be known in advance for the accurate implementation of e-Governance projects. Simple language and purpose must be considered as the major objectives of e-governance.

5. Maintenance expenses should be borne by the citizens against the facility of service provided by the government $\&$ availed by the citizens.

6. The transaction or information provided by the citizen to the government agency must be ensured. Otherwise the information can be misused by the private sector or competitors and the users may be reluctant to access the services provided.

7. Transaction security is another major problem in egovernance. The tax, fine and bill payment must be secured and the system design should be full proof.

8. Cyber law must be made as soon as possible in order to make the electronic transactions and documents of legal validity of the services provided and availed.

The e-Governance applications must have this characteristic so that the newly developed and existing applications can be implemented together. E-Governance in order to affect every citizen of the country the applications must have the scale to interface with every citizen. Multimodal interaction provides the user with multiple modes of interfacing with a system. An eGovernment application can only be effective if its users can access it using different devices (Felix et al., 2011).

\section{E-Governance Project Failure - Facts and Reasons}

The successful adoption of e-governance can be achieved by developing a set of e-government adoption factors and by investigating the connected relationships of those factors on its performance. E-Governance is enabling to provide the government services to the common man in a very cost effective manner as effective promotion schemes are being taken up by the Indian government in order to provide quality services to the citizens as there is huge potential for the development of e-governance in various fields (Sanjay et al., 2010).

$35 \%$ of e-Government projects are total Failures because of the Initiatives which is not implemented and Initiatives abandoned immediately. $50 \%$ of eGovernment projects are partial failures because the main targeted goals are not achieved or at times initial success but failure after a year. 
Table No. 6.1 Reasons \& Causes of Project Failures

\begin{tabular}{|c|c|}
\hline $\begin{array}{l}\text { Project } \\
\text { Definition }\end{array}$ & Lack of a failure proof project plan with Undefined objectives and goals \\
\hline Scope & $\begin{array}{l}\text { - Inadequate planning and poor containment of the project scope } \\
\text { - Meeting end user expectations / business benefits } \\
\text { - No Change Control System }\end{array}$ \\
\hline Cost & - Poor project estimations and overruns of schedule and cost \\
\hline Time & $\begin{array}{l}\text { - Unrealistic timeframes and tasks and lack of prioritization } \\
\text { - Lack of management commitment }\end{array}$ \\
\hline Communication & - Infrequent communication between project units and other stakeholders \\
\hline Quality & - Lack of skills, inadequate testing processes and not meeting expectations \\
\hline Risk & $\begin{array}{l}\text { - No authority to project warning signs } \\
\text { - Poor control of outsourcing }\end{array}$ \\
\hline Procurement & - Vagueness in specifying requirements leading to undesirable procurement \\
\hline $\begin{array}{l}\text { Human } \\
\text { Resource }\end{array}$ & $\begin{array}{l}\text { - Poor management of expectations, roles and responsibilities, } \\
\text { - Ineffective resource management } \\
\text { - Lack of organizational support } \\
\text { - Lack of User Involvement } \\
\text { - Stakeholder conflict }\end{array}$ \\
\hline
\end{tabular}

Source: www.nisg.org/docs/539_Report.pdf

Success for one group but failure for others $15 \%$ of eGovernment projects are successes only because of all stakeholders benefited and which resulted with no adverse results (www.nisg.org/docs/539_Report.pdf).

In India, challenges of weak governance, cost, time, quality, risk, procurement, capacity building, poverty, and bureaucratic corruption among others is very much engaged with the successful application of e-governance. The electronic mode motivating reforms, therefore, are capable of engage greater citizens' involvement in policy formulation, responsive governance and administration, beyond, ushering global best practices that cultural and contextual compatible (Gajendra et al., 2012).

\section{Conclusion}

Therefore, the e-readiness of India is still low. There are various challenges for the implementing of e-government project in India. To overcome the challenges of implementation a vision is required to implement the egovernment in India in an adequate manner. The cultural norms and patterns of individual behavior affect the manner in which technology is used by citizens. There is need to develop effective implementation of egovernment in India in order to serve the citizens. In order to match the digital divide gap in the country there is a need to develop an environment for e-government by overcoming the challenges of e-government. Implementation of e-government conceptual framework which can be further validated in the real life situation is developed for the effective implementation of egovernment in India.

\section{References}

Almarabeh, T., A. AbuAli. 2010. "A General Framework for E-Government: Definition Maturity Challenges, Opportunities, and Success", European J. Scientific Res., Vol 39, No 1

Bharat Maheshwari, Vinod Kumar, Uma Kuma and Vedmani Sharan. 2007. "E-Government Portal Effectiveness: Managerial Considerations for Design and Development", The Int. J. E-government \& Policy.

Carolyne Stanforth. 2010. "Analysing e-Government Project Failure: Comparing Factoral, Systems and Interpretive Approaches", Development Policy and Management, University of Manchester, Manchester.

Das, R.K., M.R. Patra. 2013. "A Service Oriented Design Approach for e-Governance Systems", Int. 
J. Information Technol. Convergence and Services, Pp 1-11.

Dawes, S.S. 2008. "The Evolution and Continuing Challenges of E-Governance", Public Administration Review, Pp 86-100.

Felix, S., P. Kumar, N. Vijaykumar. 2011. "eGovernance Projects: Exploring the Way to Success", SET Labs Briefings, Vol 9, No 2.

Gajendra, S., B. Xi, \& Q. Wang. 2012. "E-Government: Public Participation and Ethical Issues", J. EGovernance, Pp.195-204.

Mamta Mokta, S.S. Chahan, Sanjeev, K. Mahajan and Simmi Agnihotri. 2011. "Challenges in Governance", Anamika Publisher and Distributors Private Limited, New Delhi.

Pardeep Mittal and Amandeep Kaur. 2013. "EGovernance - A challenge for India", Int. J. Adv. Res. Computer Engineering \& Technol., Vol 2, No 3.

\section{How to cite this article:}

Ramnik Kaur. 2017. An Analysis of Electronic Governance: Deliverance of Public Electronic Services at the front desk level in India. Int.J.Curr.Res.Aca.Rev. 5(1), 77-83. doi: http://dx.doi.org/10.20546/ijcrar.2017.501.009 